\title{
Histoplasmosis and Tuberculosis Co-Occurrence in People with Advanced HIV
}

\author{
Diego H. Caceres $1,2, *,+\left(\mathbb{C}\right.$ and Audrey Valdes ${ }^{3, *,+}$ \\ 1 Mycotic Diseases Branch, Centers for Disease Control and Prevention, Atlanta, GA 30333, USA \\ 2 Studies in Translational Microbiology and Emerging Diseases (MICROS) Research Group, School of \\ Medicine and Health Sciences, Universidad del Rosario, 11011 Bogota, Colombia \\ 3 Service de Maladies Infectieuses et Tropicales, Centre Hospitalier de Cayenne, 97306 Cayenne, French Guiana \\ * Correspondence: diegocaceres84@gmail.com or xju7@cdc.gov (D.H.C.); audrey.valdes@laposte.net (A.V.) \\ + Contributed equally.
}

Received: 14 July 2019; Accepted: 7 August 2019; Published: 9 August 2019

check for updates

\begin{abstract}
Distinguishing between histoplasmosis, tuberculosis (TB), and co-occurrence of disease is a frequent dilemma for clinical staff treating people with advanced Human Immunodeficiency Virus (HIV) infection. This problem is most frequently observed in clinical settings in countries where both diseases are endemic. It is also a challenge outside these endemic countries in HIV clinics that take care of patients coming from countries with endemic histoplasmosis and TB. The gold standard for diagnosis of both of these diseases is based on conventional laboratory tests (culture, histopathology and special stains). These tests have several limitations, such as lack of laboratory infrastructure for handling isolates (biosafety level 3), shortage of laboratory staff who have appropriate training and experience, variable analytical performance of tests and long turn-around time. Recently, novel rapid assays for the diagnosis of histoplasmosis and TB became available. However, this technology is not yet widely used. Mortality in immunocompromised patients, such as people with advanced HIV, is directly linked with the ability to rapidly diagnose opportunistic diseases. The aim of this review is to synthesize the main aspects of epidemiology, clinical characteristics, diagnosis and treatment of histoplasmosis/TB co-occurrence in people with advanced HIV.
\end{abstract}

Keywords: histoplasmosis; tuberculosis; HIV; AIDS; co-occurrence; epidemiology; diagnosis; treatment

\section{Introduction}

A wide variety of opportunistic diseases occurs in people with advanced HIV depending on CD4 counts. The lower this count, the higher the risk of multiple infections. Tuberculosis (TB) is one of the main opportunistic infections around the world, with an estimated burden of 1.3 million new disease cases/year, and 300,000 deaths/year among people living with HIV (PLHIV) [1]. Histoplasmosis, caused by the dimorphic fungus Histoplasma capsulatum, has been reported worldwide, but most cases have been identified in the Americas [2]. In contrast to TB, the burden of histoplasmosis is less well known. Studies from the 1950s using intradermal reaction (IDR) with histoplasmin revealed the high prevalence of people with exposure to Histoplasma in the general population in the Americas and some regions in Asia and Africa [3-5]. One epi-serological study done in 1960 in Michigan, United States, showed that $26 \%$ of the general population had intradermal reaction against tuberculin or histoplasmin, and $5 \%$ to both antigens [6].

No global estimate of the histoplasmosis burden in PLHIV is available, and in many endemic countries, estimating histoplasmosis burden is not feasible due to lack of data [7-10]. A recent report provided an estimate of the histoplasmosis burden in PLHIV in Latin American countries using 
data from previous IDR studies [11]. Authors estimated that in some countries, the prevalence of histoplasmosis and TB were equivalent, but histoplasmosis caused more deaths compared with TB. Studies based on autopsies in Brazil and Peru identified $7 \%-28 \%$ of deaths as related to tuberculosis and $12 \%-21 \%$ of deaths related to histoplasmosis [12,13]. A retrospective review of histoplasmosis cases reported mortality rates of $20 \%-53 \%$ [14].

The poor understanding of histoplasmosis prevalence and the lack of disease awareness among clinicians are directly linked to the clinical confusion between histoplasmosis and tuberculosis. Patients with histoplasmosis are often initially diagnosed and treated for TB, resulting in treatment failure $[15,16]$.

\section{Materials and Methods}

Literature search: We searched the following databases for the terms histoplasmosis, HIV and tuberculosis, including synonyms in the title, abstract, keywords or subject headings: Medline (Ovid), Embase (Ovid), CAB Abstracts (Ovid), Global Health (Ovid), Scopus, the Cochrane Library, PubMed Central and LILACS. These searches were limited to studies published in English, Spanish and Portuguese. We searched for reports of cohorts of patients with progressive disseminated histoplasmosis and HIV, and frequency of TB disease co-occurrence. We aimed to synthesize the main aspects of epidemiology, clinical characteristics, diagnosis and treatment of histoplasmosis/TB co-occurrence in people with advanced HIV.

\section{Epidemiology of Histoplasmosis/TB Co-Occurrence in People with Advanced HIV}

Symptoms of histoplasmosis are nonspecific and often indistinguishable from those of other infectious diseases, especially TB. This complicates the clinical diagnosis and treatment. Co-occurrence of TB has been reported in several cohorts of patients with histoplasmosis and advanced HIV from Latin American countries (Figure 1). Patients with this co-occurrence share the following common characteristics: (1) They are often highly immunosuppressed (median CD4 T cell: 30 cells $/ \mathrm{mm}^{3}$ ). (2) In most of these studies, TB diagnosis was done by direct microscopic observation of acid-fast-bacilli (AFB) in specimens from symptomatic people, without microbiological confirmation by culture. (3) Treatment failures were frequently reported [17-26]. Based on these reports, it is important to highlight the key role of laboratory testing in the diagnosis of histoplasmosis or $\mathrm{TB}$, or the co-occurrence of these two conditions. In order to a quickly diagnose and treat patients, and improve patient outcomes, accurate laboratory testing should be done if there is any suspicion that a patient might have histoplasmosis, $\mathrm{TB}$ or other diseases.
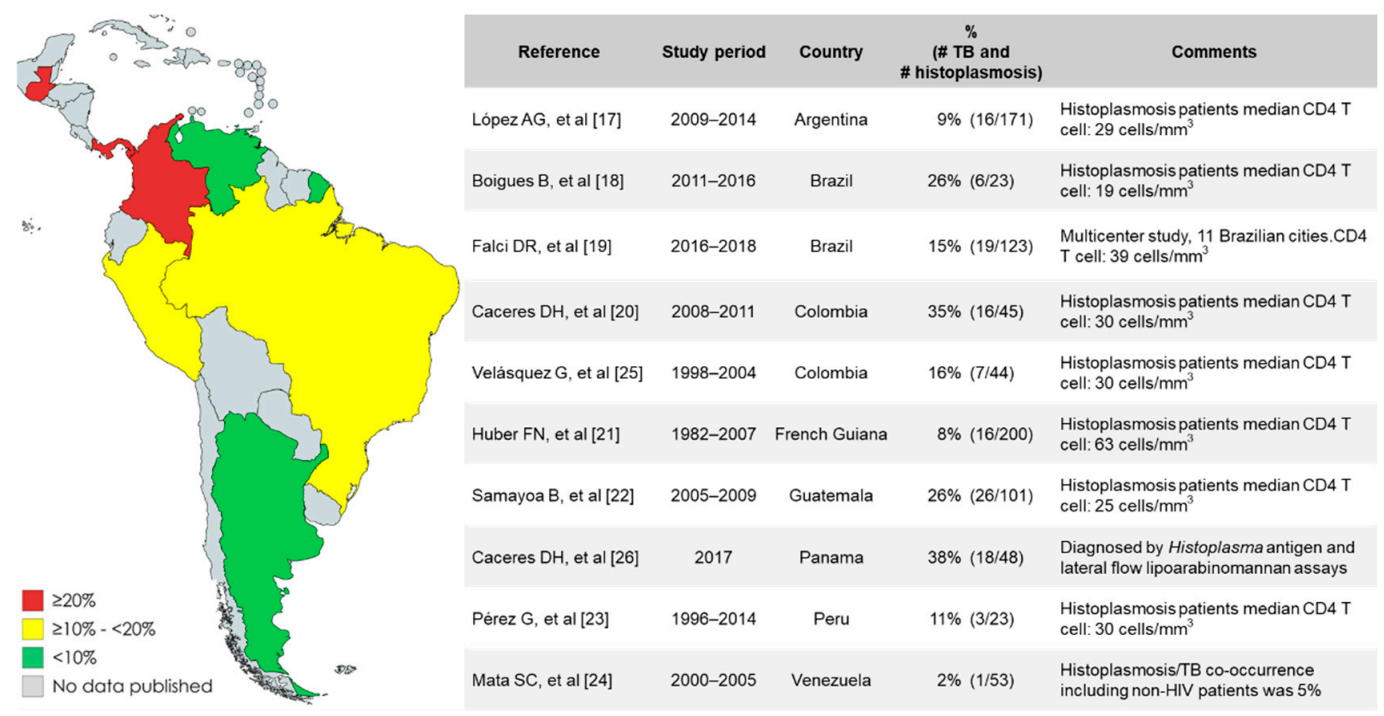

Figure 1. Reports of cohorts of people with histoplasmosis and advanced HIV: frequency of tuberculosis (TB) co-occurrence. 


\section{Clinical Characteristics}

Histoplasmosis and tuberculosis are frequently identified in patients with advanced HIV (CD4 $\mathrm{T}$ cells under $200 / \mathrm{mm}^{3}$ ). Two clinical presentations are frequently described, the pulmonary and the progressive disseminated form. However, it is often difficult to differentiate between the two diseases [27-29]. Common symptoms include fever, weight loss and respiratory symptoms. Chest imaging often shows localized pulmonary lesions or miliary nodules. Multiple organs can become involved including: lymph nodes, bone marrow, spleen, liver, digestive tract, adrenal gland and central nervous system $[30,31]$. In clinical descriptions of people with histoplasmosis and TB co-occurrence, fever was the most common manifestation (75\%), and half (50\%) of the cases presented lymph node enlargement, gastrointestinal (mostly abdominal) pain and respiratory symptoms, dominated by an isolated cough. Three of seven patients $(43 \%)$ with a reported outcome died. Histoplasmosis diagnosis was delayed in non-endemic countries [32-37].

Several studies have tried to identify clinical patterns for differentiating histoplasmosis and TB disease in PLHIV. A study from French Guiana used a multivariate model to compare symptoms in HIV patients infected with either histoplasmosis or TB alone and identified a specific clinical and biological profile. Within this profile, disseminated histoplasmosis appeared to have a prominent gastrointestinal tract involvement, while disseminated tuberculosis had a concomitant pulmonary expression [38]. In a study from Colombia, a multidimensional statistical method was used to identify a clinical profile in patients with histoplasmosis and advanced HIV; results on this study were similar to the results reported from French Guiana [20]. However, it was not possible to unambiguously diagnose histoplasmosis/TB co-occurrence in PLHIV based solely on the clinical evaluation of signs and symptoms. This finding highlights the need for specific diagnostic tests for histoplasmosis, TB and co-occurrence, in order to reduce diagnostic delays and improve patient outcomes.

Gold standards for the diagnosis of histoplasmosis and TB are based on conventional laboratory methods that include histopathological analysis, special stains and culture [2,39-42]. For the diagnosis of pulmonary TB, analysis of sputum samples by microscopic observation of AFB is widely available and can provide results quickly and with acceptable analytical performance. On the other hand, for the diagnosis of pulmonary histoplasmosis, sputum samples are not appropriate. In order to increase the sensitivity, it is necessary to analyze invasive respiratory samples like bronchoalveolar lavage (BAL) fluid, or other lower respiratory tract specimens [2,27,41]. For the diagnosis of disseminated TB and histoplasmosis, it is necessary to test samples from the tissue involved; yet obtaining such invasive samples could present a risk for complications in critically ill patients. Blood cultures and bone marrow culture are useful to diagnose disseminated TB and histoplasmosis. High sensitivity is observed when samples are processed using tests based on lysis systems (>80\% sensitivity) [43-46]. Conventional laboratory methods have many challenges, including the need for complex laboratory infrastructure (biosafety level 3 laboratories), personnel with extensive training and competency in microbiology, delays of several weeks for final laboratory results and variable analytical performance. For example, the sensitivity of histoplasmosis culture testing ranges from $42 \%$ to $74 \%$ and depends on the clinical form of the disease and specimen quality $[2,27,41]$.

For histoplasmosis diagnosis, antibody detection tests are less sensitive in PLHIV, with a sensitivity ranging between $38 \%$ to $70 \%[27,41,47]$. Assays for intradermal reaction or interferon- $\gamma$ release assays are not commercially available. Recently the development of an interferon gamma release assay specific for Histoplasma capsulatum, aimed to detect asymptomatic infected individuals was reported; future validations are necessary to know the analytical performance of this assay [48]. Conversely, detection of circulating Histoplasma antigen has proven highly sensitive $(>90 \%)$ [49]. Since 1986, this test has been offered by a private laboratory in the United States of America (MiraVista Diagnostics ${ }^{\mathrm{TM}}$, Indianapolis, IN, USA), and some commercial ELISA kits are available in the market. One commercial kit (Histoplasma Galactomannan EIA, IMMY' ${ }^{\mathrm{TM}}$, Norman, OK, USA) has shown high analytical performance with internal and external laboratory reproducibility in a multicenter validation in two Latin American countries [50]. A lateral flow device was recently developed. This technology shows the same analytical 
performance as the ELISA methodology, but in contrast to the ELISA test, it can be performed in less complex laboratories, requires less time and can potentially reduce the costs associated with the test's performance [51]. Additionally, antigen detection has increased detection of histoplasmosis cases and reduced mortality in Colombia, India, Guatemala and Brazil [19,22,52,53].

Diagnosis of infection with Mycobacterium tuberculosis can be performed by antibody and antigen detection [40]. Tuberculin skin testing and interferon- $\gamma$ release assays are available for diagnosis of latent $M$. tuberculosis infection. These tests are recommended for people at risk of developing tuberculosis. Those with a positive test result can be treated to reduce the possibility of developing active TB disease [40,54]. A lateral flow urine lipoarabinomannan assay (LF-LAM) is also available (Alere Determine ${ }^{\mathrm{TM}}$ TB LAM, Abbott, Chicago, IL, USA). The World Health Organization (WHO) recommended the LF-LAM to assist in the diagnosis of TB in PLHIV with signs and symptoms of TB and low CD4 cell count $(<100$ cells/ $/ \mathrm{L})$ [55].

There are no commercial PCR kits for the diagnosis of histoplasmosis directly on patient specimens. The only available commercial kit is for the identification of culture isolates. Several in-house PCR assays have been developed, but the analytical performance of these tests is variable [56-62]. This variation could be due to the lack of consensus on gene targets, DNA extraction methods, laboratory procedures, sample type, etc. Molecular tests look promising for histoplasmosis diagnosis, but further investigations are needed for protocol standardization.

Many different alternatives for TB diagnosis and antimicrobial resistance are available commercially. The Xpert MTB/RIF Ultra test (Cepheid, Sunnyvale, CA, USA) is one of the most available tests. This is a non-culture based real-time PCR, able to detect $M$. tuberculosis DNA and mutations associated with resistance to rifampicin direct on a patient's specimens in less than two hours $[63,64]$. Other molecular commercial tests are available, including RealTime MTB (Abbott, IL, USA), FluoroType MTBDR (Bruker, Billerica, MA, USA), Anyplex TM II MTB/XDR (Seegene, Seoul, Korea) and BD MAX MDR-TB (Beckton, Dickinson and Company, Franklin Lakes, NJ, USA). Currently, Matrix-assisted laser desorption ionization-time-of-flight (MALDI-TOF) mass spectrometry is one of the best options for identification of Mycobacterium species isolates. This technology is quick and highly accurate for isolate identification.

In November 2018, the World Health Organization (WHO) published the first essential diagnostics list [65]. This list contains 113 products, 58 for detection and diagnosis of a wide range of common conditions, and the remaining 55 for diagnosis and monitoring of priority diseases such as HIV, tuberculosis, malaria, hepatitis B and C, human papillomavirus and syphilis. This first version did not include any laboratory test for the diagnosis of histoplasmosis, but the Second WHO Model List of Essential In Vitro Diagnostics published at the end of July 2019, includes the Histoplasma antigen testing [66].

\section{Treatment of Histoplasmosis/TB Co-Occurrence}

In 2017, the WHO released guidelines to address advanced HIV disease, including screening, diagnosis and treatment of the most common opportunistic diseases in HIV-infected people [67]. These guidelines noted that consideration should be given to regional differences in comorbidities and coinfections but did not specifically provide guidance on diagnosis and management of histoplasmosis. The Infectious Diseases Society of America (IDSA) developed histoplasmosis treatment guidelines in 2007. These guidelines have limitations for implementation outside of the United States, as they do not follow the guideline development methodology that has been standardized by the WHO and do not describe management of TB co-occurrence in PLHIV with histoplasmosis [68].

The IDSA guidelines recommend treatment according to disease severity: moderate to severe, and mild to moderate. For moderately severe to severe disease, the recommended treatment includes liposomal amphotericin B (3.0 mg/kg daily, 1-2 weeks), followed by oral itraconazole (200 mg 3 times daily for 3 days and then $200 \mathrm{mg}$ twice daily for a total of at least $12 \mathrm{months})$. Deoxycholate amphotericin $\mathrm{B}(0.7-1.0 \mathrm{mg} / \mathrm{kg}$ daily) is an alternative in patients who are at a low risk for nephrotoxicity. For mild to 
moderate disease, treatment includes itraconazole ( $200 \mathrm{mg} 3$ times daily for 3 days and then twice daily for at least 12 months). Blood levels of itraconazole and Histoplasma antigen concentrations (sera or urine) should be measured during therapy. Histoplasma antigen concentrations should be monitored for 12 months after the end of the therapy to detect early signs of relapse [68]. Table 1 summarizes the recommendations for treatment of histoplasmosis and itraconazole interactions.

Table 1. Recommendation for treatment of histoplasmosis in persons living with HIV (PLHIV).

\begin{tabular}{|c|c|}
\hline Itraconazole drug interactions & $\begin{array}{c}\text { Antibacterial for TB treatment: } \\
\text { - Rifampicin and rifabutin may decrease itraconazole blood levels } \\
\text { - Itraconazole may increase blood levels of rifabutin } \\
\text { Antiretroviral: } \\
\text { - Efavirenz (EFV) and nevirapine (NVP) reduce itraconazole blood levels } \\
\text { - Lopinavir/ritonavir (LPV/r) and atazanavir/ritonavir (ATV/r) increase } \\
\text { itraconazole blood levels } \\
\text { Monitoring itraconazole blood levels. }\end{array}$ \\
\hline $\begin{array}{l}\text { Recommendations for treatment of } \\
\text { progressive disseminated } \\
\text { histoplasmosis } \\
\text { (Infectious Diseases Society of America } \\
\text { (71) guidelines) }\end{array}$ & $\begin{array}{l}\text { Moderately severe to severe disease: } \\
\text { - Liposomal amphotericin B ( } 3.0 \mathrm{mg} / \mathrm{kg} \text { daily, } 1-2 \text { weeks), followed by oral } \\
\text { itraconazole ( } 200 \mathrm{mg} 3 \text { times daily for } 3 \text { days and then } 200 \mathrm{mg} \text { twice daily } \\
\text { for a total of at least } 12 \text { months in disseminated form) [68]. } \\
\text { For mild to moderate disease: } \\
\text { - Itraconazole ( } 200 \mathrm{mg} 3 \text { times daily for } 3 \text { days and then twice daily for at } \\
\text { least } 12 \text { months) [68]. } \\
\text { Blood levels of itraconazole and Histoplasma antigen concentrations (sera or } \\
\text { urine) should be measured during therapy. Monitor Histoplasma antigen } \\
\text { concentrations for } 12 \text { months after end of therapy with the aim of early } \\
\text { identification of histoplasmosis relapse [68]. }\end{array}$ \\
\hline $\begin{array}{l}\text { Treatment of histoplasmosis/TB } \\
\text { co-occurrence }\end{array}$ & $\begin{array}{l}\text { At the time of this review, there were no guidelines for the treatment of } \\
\text { histoplasmosis/TB co-occurrence. } \\
\text { A report from Colombia used fluoroquinolone as an alternative agent in } \\
\text { place of rifampicin for tuberculosis [69]. This was a descriptive study with } \\
\text { evidence of a very low certainty. }\end{array}$ \\
\hline
\end{tabular}

Itraconazole can interactwith several antibacterial and retroviral (ART) medications. The TB treatment medications rifampicin and rifabutin can decrease levels of itraconazole, and itraconazole can increase levels of rifabutin. On the other hand, the ART drugs, efavirenz (EFV) and nevirapine (NVP) reduces itraconazole blood levels, and lopinavir/ritonavir (LPV/r) and atazanavir/ritonavir (ATV/r) increases itraconazole blood levels. For that reason, it is necessary to monitor itraconazole blood concentration during time of treatment. Currently, there are no guidelines or recommendations for the treatment of the histoplasmosis/TB co-occurrence. A study from Colombia describes a case series of 12 PLHIV with histoplasmosis/TB co-occurrence treated with itraconazole. The authors describe two groups of treatment: (1) itraconazole plus rifampicin + isoniazid + pyrazinamide + ethambutol (RHZE) ( $n=6$ patients), and (2) itraconazole plus isoniazid + pyrazinamide + ethambutol (HZE), plus a quinolone ( $n=6$ patients). In group 1 , they found therapeutic itraconazole blood levels in 0 of 3 patients measured, treatment success in 4 of 6 patients, 1 patient's death and 1 histoplasmosis relapse. In group 2, they found therapeutic itraconazole blood levels in 2 of 2 patients measured, success treatment in 5 of 6 patients, and one patient was lost to follow-up [69]. A problem in this patient population is that the ARV introduction is usually delayed by two weeks due to the risk of immune reconstitution inflammatory syndrome [70].

\section{Conclusions}

People living with HIV are at a high risk for developing multiple opportunistic diseases, and the evaluation of clinical signs and symptoms is not enough to establish a final diagnosis. Although recent technological advances have improved diagnostic accuracy of advanced HIV-related opportunistic diseases, these technologies are not available in many regions around the world. In addition, fungal opportunistic diseases are neglected in most of the HIV programs worldwide, resulting in inadequate 
health system planning and missed opportunities to save lives. Focus areas are the role of education, networking and access to accurate laboratory tests used to promptly confirm correct diagnoses and provide appropriate therapies.

Based on the findings of this review, tuberculosis co-occurrence is a frequent problem in people with histoplasmosis and advanced HIV; most of the reports came from the Latin American region and involved very ill patients (median CD4 T cell: 30 cells $/ \mathrm{mm}^{3}$ ). The lack of epidemiological data, diseases awareness, rapid accurate diagnostics tests and treatment guidelines are the main threats to this patient population. These gaps could be improved by: (1) improving the histoplasmosis epidemiological data through the implementation of surveillance systems; (2) increasing histoplasmosis disease awareness by implementing educational strategies, such as the inclusion of histoplasmosis in national HIV program guidelines; and (3) increasing awareness of novel rapid diagnostic tests for histoplasmosis, TB and other opportunistic diseases.

Author Contributions: D.H.C. and A.V. contributed equally in the production of this review, including literature review, data extraction and analysis, and paper writing.

Funding: This work was funded by Oak Ridge Institute for Science and Education (ORISE) as part of a research fellowship for Diego H. Caceres.

Acknowledgments: We want to thank Mark Mezzullo, Kaitlin Benedict and Pooja Gandhi for editing the manuscript, and Martha Knuth, Librarian at the Stephen B. Thacker, CDC Library, as well as the Centers for Disease Control and Prevention, the Center for Surveillance, Epidemiology, and Laboratory Services (CSELS), and the Division of Public Health Information Dissemination (DPHID).

Conflicts of Interest: The findings and the conclusions in this report are those of the authors and do not necessarily represent the official position of the Centers for Disease Control and Prevention.

\section{References}

1. World Health Organization (WHO). Global Tuberculosis Report 2018. Available online: https://www.who. int/tb/publications/global_report/en/ (accessed on 14 July 2019).

2. Deepe, G.S. Histoplasma capsulatum (histoplasmosis). In Principles and Practice of Infectious Diseases, 8th ed.; Bennett, J.E., Dolin, R., Blaser, M.J., Eds.; Elsevier: Amsterdam, The Netherlands, 2015; pp. 2949-2962.

3. Edwards, P.Q.; Klaer, J.H.; Principe, A.; Convit, J.; Pifano, F.; Dodge, H.J. Worldwide geographic distribution of histoplasmosis and histoplasmin sensitivity. Am. J. Trop. Med. Hyg. 1956, 5, 235-257. [CrossRef] [PubMed]

4. Oladele, R.O.; Ayanlowo, O.O.; Richardson, M.D.; Denning, D.W. Histoplasmosis in Africa: An emerging or a neglected disease? PLoS Negl. Trop. Dis. 2018, 12, e0006046.

5. Bahr, N.C.; Sarosi, G.A.; Meya, D.B.; Bohjanen, P.R.; Richer, S.M.; Swartzentruber, S.; Halupnick, R.; Jarrett, D.; Wheat, L.J.; Boulware, D.R. Seroprevalence of histoplasmosis in Kampala, Uganda. Med. Mycol. 2016, 54, 295-300.

6. Dodge, H.J.; Payne, M.W.; Whitehouse, W.M.; Bauman, K.A. Estimates of the Prevalence of Tuberculous and Histoplasmal Infections in a Sample of the Population of Tecumseh, Michigan, 1960. Am. Rev. Respir Dis. 1965, 92, 459-469. [PubMed]

7. Macedo-Vinas, M.; Denning, D.W. Estimating the Burden of Serious Fungal Infections in Uruguay. J. Fungi 2018, 4, 37. [CrossRef] [PubMed]

8. Medina, N.; Samayoa, B.; Lau-Bonilla, D.; Denning, D.W.; Herrera, R.; Mercado, D.; Guzmán, B.; Pérez, J.C.; Arathoon, E. Burden of serious fungal infections in Guatemala. Eur. J. Clin. Microbiol. Infect. Dis. 2017, 36, 965-969.

9. Mandengue, C.E.; Ngandjio, A.; Atangana, P.J. Histoplasmosis in HIV-Infected Persons, Yaounde, Cameroon. Emerg. Infect. Dis. 2015, 21, 2094-2096. [CrossRef] [PubMed]

10. Lai, C.H.; Lin, H.H. Cases of histoplasmosis reported in Taiwan. J. Formos. Med. Assoc. 2006, 105, 527-528. [CrossRef]

11. Adenis, A.A.; Valdes, A.; Cropet, C.; McCotter, O.Z.; Derado, G.; Couppie, P.; Chiller, T.; Nacher, M. Burden of HIV-associated histoplasmosis compared with tuberculosis in Latin America: A modelling study. Lancet Infect. Dis. 2018, 18, 1150-1159. [CrossRef] 
12. Souza, S.L.; Feitoza, P.V.; Araujo, J.R.; Andrade, R.V.; Ferreira, L.C. Causes of death among patients with acquired immunodeficiency syndrome autopsied at the Tropical Medicine Foundation of Amazonas. Rev. Soc. Bras. Med. Trop. 2008, 41, 247-251. [CrossRef] [PubMed]

13. Dominique, E.; Cerrillo, G.; Castro, C.; Ticona, E.; Morales, D.; Herrera, P.M.; Alfaro, A.; Cabanillas, J.; Barrantes, F.; Benavides, A.; et al. Resultados post mórtem e infecciones oportunistas en pacientes VIH-positivos de un hospital público del Perú. Rev. Peru. Med. Exp. Salud Publica 2006, 23, 270-274.

14. Cáceres, D.H.; Gómez, B.L.; Restrepo, Á.; Tobón, Á.M. Histoplasmosis y sida: Factores de riesgo clínicos y de laboratorio asociados al pronóstico de la enfermedad. Infectio 2012, 16, 44-50.

15. Gopalakrishnan, R.; Nambi, P.S.; Ramasubramanian, V.; Abdul Ghafur, K.; Parameswaran, A. Histoplasmosis in India: Truly uncommon or uncommonly recognised? J. Assoc. Physicians India 2012, 60, 25-28. [PubMed]

16. Bulmer, A.C.; Bulmer, G.S. Incidence of histoplasmin hypersensitivity in the Philippines. Mycopathologia 2001, 149, 69-71. [CrossRef] [PubMed]

17. López Daneri, A.G.; Arechavala, A.; Iovannitti, C.A.; Mujica, M.T. Histoplasmosis diseminada en pacientes HIV/SIDA: Buenos Aires, 2009-2014. Medicina 2016, 76, 332-337. [PubMed]

18. Boigues, B.C.S.; Paniago, A.M.M.; Lima, G.M.E.; Nunes, M.O.; Uehara, S.N.O. Clinical outcomes and risk factors for death from disseminated histoplasmosis in patients with AIDS who visited a high-complexity hospital in Campo Grande, MS, Brazil. Rev. Soc. Bras. Med. Trop. 2018, 51, 155-161. [CrossRef]

19. Falci, D.R.; Monteiro, A.A.; Braz Caurio, C.F.; Magalhaes, T.C.O.; Xavier, M.O.; Basso, R.P.; Melo, M.; Schwarzbold, A.V.; Ferreira, P.R.A.; Vidal, J.E.; et al. Histoplasmosis, An Underdiagnosed Disease Affecting People Living with HIV/AIDS in Brazil: Results of a Multicenter Prospective Cohort Study Using Both Classical Mycology Tests and Histoplasma Urine Antigen Detection. In Open Forum Infectious Diseases; Oxford University Press: Oxford, UK, 2019; Volume 6, p. ofz073.

20. Caceres, D.H.; Tobon, A.M.; Cleveland, A.A.; Scheel, C.M.; Berbesi, D.Y.; Ochoa, J.; Restrepo, A.; Brandt, M.E.; Chiller, T.; Gómez, B.L.; et al. Clinical and Laboratory Profile of Persons Living with Human Immunodeficiency Virus/Acquired Immune Deficiency Syndrome and Histoplasmosis from a Colombian Hospital. Am. J. Trop. Med. Hyg. 2016, 95, 918-924. [CrossRef] [PubMed]

21. Huber, F.; Nacher, M.; Aznar, C.; Pierre-Demar, M.; El Guedj, M.; Vaz, T.; Vincent, V.; Abba, M.; Christian, M.; Elodie, C.; et al. AIDS-related Histoplasma capsulatum var. capsulatum infection: 25 years experience of French Guiana. Aids 2008, 22, 1047-1053. [CrossRef] [PubMed]

22. Samayoa, B.; Roy, M.; Cleveland, A.A.; Medina, N.; Lau-Bonilla, D.; Scheel, C.M.; Gomez, B.L.; Chiller, T.; Arathoon, E. High Mortality and Coinfection in a Prospective Cohort of Human Immunodeficiency Virus/Acquired Immune Deficiency Syndrome Patients with Histoplasmosis in Guatemala. Am. J. Trop. Med. Hyg. 2017, 97, 42-48. [CrossRef]

23. Perez-Lazo, G.; Maquera-Afaray, J.; Mejia, C.R.; Castillo, R. Disseminated histoplasmosis and HIV infection: Case series in a Peruvian hospital. Rev. Chilena Infectol. 2017, 34, 365-369.

24. Mata-Essayag, S.; Colella, M.T.; Rosello, A.; de Capriles, C.H.; Landaeta, M.E.; de Salazar, C.P.; Sylvia, M.; Carolina, O.; Maria, C.I.; Liseloth, G. Histoplasmosis: A study of 158 cases in Venezuela, 2000-2005. Medicine 2008, 87, 193-202. [CrossRef]

25. Uribe, G.V.; Rueda, Z.V.; Vélez, L.A.; Aguirre, D.C.; Gómez-Arias, R.D. Histoplasmosis en pacientes con sida. Un estudio de cohorte en Medellín, Colombia. Infectio 2010, 14, 99-106.

26. Caceres, D.H.; Arauz, A.B.; Flores, C.; Santiago, E.; Gutiérrez, E.; Borace, J.; Abdo, J.; Lindsley, M.; Flores, R.; Stolz-Sobalvarro, E.; et al. Tuberculosis and histoplasmosis diagnosis among people living with HIV/AIDS: The impact of using rapid diagnostics tests in Panama. In Proceedings of the 20th Congress of the International Society for Human and Animal Mycology, Amsterdam, The Netherlands, 4 June 2018.

27. Kauffman, C.A. Diagnosis of histoplasmosis in immunosuppressed patients. Curr. Opin. Infect. Dis. 2008, 21, 421-425. [CrossRef]

28. Sacarlal, J.; Denning, D.W. Estimated Burden of Serious Fungal Infections in Mozambique. J. Fungi 2018, 4, 75. [CrossRef] [PubMed]

29. Salahuddin, M.; Karanth, S.; Ocazionez, D.; Estrada, Y.M.R.M.; Cherian, S.V. Clinical Characteristics and Etiologies of Miliary Nodules in the US: A Single-Center Study. Am. J. Med. 2019, 132, 767-769. [CrossRef] [PubMed] 
30. Aaron, L.; Saadoun, D.; Calatroni, I.; Launay, O.; Memain, N.; Vincent, V.; Marchal, G.; Dupont, B.; Bouchaud, O.; Valeyre, D.; et al. Tuberculosis in HIV-infected patients: A comprehensive review. Clin. Microbiol. Infect. 2004, 10, 388-398. [CrossRef] [PubMed]

31. Swaminathan, S.; Padmapriyadarsini, C.; Narendran, G. HIV-associated tuberculosis: Clinical update. Clin. Infect. Dis. 2010, 50, 1377-1386. [CrossRef] [PubMed]

32. Garzona-Schmidt, R.; Solano-Chinchilla, A. Úlceras Colónicas por TB e Histoplasmosis en un paciente portador de VIH/Sida. Acta Méd. Costarric. 2001, 43, 138-140.

33. Greene, L.; Peters, B.; Lucas, S.B.; Pozniak, A.L. Extrapulmonary tuberculosis masking disseminated histoplasmosis in AIDS. Sex. Transm. Infect. 2000, 76, 54-56. [CrossRef] [PubMed]

34. Jeong, H.W.; Sohn, J.W.; Kim, M.J.; Choi, J.W.; Kim, C.H.; Choi, S.H.; Kim, J.; Cho, Y. Disseminated histoplasmosis and tuberculosis in a patient with HIV infection. Yonsei Med. J. 2007, 48, 531-534. [CrossRef] [PubMed]

35. Piscoya Rivera, A.; Cedron Cheng, H.; Huerta-Mercado Tenorio, J.; Pinto Valdivia, J.L.; Ferrufino Llach, J.C.; Bussalleu Rivera, A. GI tuberculosis and histoplasmosis in an HIV (+) patient presenting with lower GI bleeding. Am. J. Gastroenterol. 2005, 100, 1896-1897. [PubMed]

36. Rezende, R.E.; Brunaldi, M.O.; Girao, M.S.; Zucoloto, S.; Garcia, S.B.; Machado, A.A.; Módena, J.L.P. Case report: Esophageal histoplasmosis associated with disseminated tuberculosis in acquired immunodeficiency syndrome. Am. J. Trop. Med. Hyg. 2009, 80, 347-350. [CrossRef] [PubMed]

37. Salzman, S.H.; Smith, R.L.; Aranda, C.P. Histoplasmosis in patients at risk for the acquired immunodeficiency syndrome in a nonendemic setting. Chest 1988, 93, 916-921. [CrossRef]

38. Adenis, A.; Nacher, M.; Hanf, M.; Basurko, C.; Dufour, J.; Huber, F.; Aznar, C.; Carme, B.; Couppie, P. Tuberculosis and histoplasmosis among human immunodeficiency virus-infected patients: A comparative study. Am. J. Trop. Med. Hyg. 2014, 90, 216-223. [CrossRef] [PubMed]

39. Fitzgerald, D.W.; Sterling, T.R.; Haas, D.W. Mycobacterium tuberculosis. In Principles and Practice of Infectious Diseases, 8th ed.; Bennett, J.E., Dolin, R., Blaser, M.J., Eds.; Elsevier: Amsterdam, The Netherlands, 2015; pp. 2234-2236.

40. Furin, J.; Cox, H.; Pai, M. Tuberculosis. Lancet 2019, 393, 1642-1656. [CrossRef]

41. Hage, C.A.; Azar, M.M.; Bahr, N.; Loyd, J.; Wheat, L.J. Histoplasmosis: Up-to-Date Evidence-Based Approach to Diagnosis and Management. Semin. Respir Crit. Care Med. 2015, 36, 729-745. [PubMed]

42. De Pauw, B.; Walsh, T.J.; Donnelly, J.P.; Stevens, D.A.; Edwards, J.E.; Calandra, T.; Pappas, P.G.; Maertens, J.; Lortholary, O.; Kauffman, C.A.; et al. Revised definitions of invasive fungal disease from the European Organization for Research and Treatment of Cancer/Invasive Fungal Infections Cooperative Group and the National Institute of Allergy and Infectious Diseases Mycoses Study Group (EORTC/MSG) Consensus Group. Clin. Infect. Dis. 2008, 46, 1813-1821. [PubMed]

43. Messina, F.A.; Corti, M.; Negroni, R.; Arechavala, A.; Bianchi, M.; Santiso, G. Histoplasmosis in AIDS patients without tegumentary manifestations. Rev. Chilena Infectol. 2018, 35, 560-565. [CrossRef] [PubMed]

44. Bianchi, M.; Robles, A.M.; Vitale, R.; Helou, S.; Arechavala, A.; Negroni, R. The usefulness of blood culture in diagnosing HIV-related systemic mycoses: Evaluation of a manual lysis centrifugation method. Med. Mycol. 2000, 38, 77-80.

45. Crump, J.A.; Reller, L.B. Two decades of disseminated tuberculosis at a university medical center: The expanding role of mycobacterial blood culture. Clin. Infect. Dis. 2003, 37, 1037-1043.

46. Ker, C.C.; Hung, C.C.; Huang, S.Y.; Chen, M.Y.; Hsieh, S.M.; Lin, C.C.; Chang, C.C.; Luh, K.T. Comparison of bone marrow studies with blood culture for etiological diagnosis of disseminated mycobacterial and fungal infection in patients with acquired immunodeficiency syndrome. J. Microbiol. Immunol. Infect. 2002, 35, 89-93. [PubMed]

47. Caceres, D.H.; Scheel, C.M.; Tobon, A.M.; Ahlquist Cleveland, A.; Restrepo, A.; Brandt, M.E.; Chiller, T.; Gómez, B.L. Validation of an enzyme-linked immunosorbent assay that detects Histoplasma capsulatum antigenuria in Colombian patients with AIDS for diagnosis and follow-up during therapy. Clin. Vaccine Immunol. 2014, 21, 1364-1368. [PubMed]

48. Rubio-Carrasquilla, M.; Santa, C.D.; Rendon, J.P.; Botero-Garces, J.; Guimaraes, A.J.; Moreno, E.; Cano, L.E. An interferon gamma release assay specific for Histoplasma capsulatum to detect asymptomatic infected individuals. Med. Mycol. 2019. Epub ahead of print. 
49. Fandino-Devia, E.; Rodriguez-Echeverri, C.; Cardona-Arias, J.; Gonzalez, A. Antigen Detection in the Diagnosis of Histoplasmosis: A Meta-analysis of Diagnostic Performance. Mycopathologia 2016, 181, 197-205. [CrossRef] [PubMed]

50. Caceres, D.H.; Samayoa, B.E.; Medina, N.G.; Tobon, A.M.; Guzman, B.J.; Mercado, D.; Restrepo, A.; Chiller, T.; Arathoon, E.E.; Gómez, B.L. Multicenter Validation of Commercial Antigenuria Reagents To Diagnose Progressive Disseminated Histoplasmosis in People Living with HIV/AIDS in Two Latin American Countries. J. Clin. Microbiol. 2018, 56, e01959.

51. Caceres, D.H.; Minderman, M.C.; Chaney, L.; Gomez, B.L.; Wheat, L.J.; Chiller, T.M.; Lindsley, M.D. Evaluation of a Histoplasma antigen Lateral Flow Assay for the rapid diagnosis of progressive disseminated histoplasmosis in AIDS patie. In Proceedings of the 20th Congress of the International Society for Human and Animal Mycology, Amsterdam, The Netherlands, 4 June 2018.

52. Caceres, D.H.; Zuluaga, A.; Arango-Bustamante, K.; de Bedout, C.; Tobon, A.M.; Restrepo, A.; Gómez, B.L.; Cano, L.E.; González, Á. Implementation of a Training Course Increased the Diagnosis of Histoplasmosis in Colombia. Am. J. Trop. Med. Hyg. 2015, 93, 662-667. [CrossRef] [PubMed]

53. Bansal, N.; Sethuraman, N.; Gopalakrishnan, R.; Ramasubramanian, V.; Kumar, D.S.; Nambi, P.S.; Chakrabarti, A. Can urinary histoplasma antigen test improve the diagnosis of histoplasmosis in a tuberculosis endemic region? Mycoses 2019, 62, 502-507. [CrossRef] [PubMed]

54. Whitworth, H.S.; Badhan, A.; Boakye, A.A.; Takwoingi, Y.; Rees-Roberts, M.; Partlett, C.; Lambie, H.; JohnInnes, F.R.C.P.; Cooke, G.; Lipman, M.M.D. Clinical utility of existing and second-generation interferon-gamma release assays for diagnostic evaluation of tuberculosis: An observational cohort study. Lancet Infect. Dis. 2019, 19, 193-202. [CrossRef]

55. WHO. The Use of Lateral Flow Urine Lipoarabinomannan Assay (LF-LAM) for the Diagnosis and Screening of Active Tuberculosis in People Living with HIV 2015. Available online: https://www.who.int/tb/publications/ use-of-lf-lam-tb-hiv/en/ (accessed on 14 July 2019).

56. Buitrago, M.J.; Canteros, C.E.; Frias De Leon, G.; Gonzalez, A.; Marques-Evangelista De Oliveira, M.; Munoz, C.O.; Ramirez, J.A.; Toranzo, A.I.; Zancope-Oliveira, R.; Cuenca-Estrella, M. Comparison of PCR protocols for detecting Histoplasma capsulatum DNA through a multicenter study. Rev. Iberoam Micol. 2013, 30, 256-260. [CrossRef] [PubMed]

57. Munoz, C.; Gomez, B.L.; Tobon, A.; Arango, K.; Restrepo, A.; Correa, M.M.; Muskus, C.; Cano, L.E.; González, A. Validation and clinical application of a molecular method for identification of Histoplasma capsulatum in human specimens in Colombia, South America. Clin. Vaccine Immunol. 2010, 17, $62-67$. [CrossRef] [PubMed]

58. Buitrago, M.J.; Gomez-Lopez, A.; Monzon, A.; Rodriguez-Tudela, J.L.; Cuenca-Estrella, M. Assessment of a quantitative PCR method for clinical diagnosis of imported histoplasmosis. Enferm. Infecc. Microbiol. Clin. 2007, 25, 16-22. [PubMed]

59. Buitrago, M.J.; Berenguer, J.; Mellado, E.; Rodriguez-Tudela, J.L.; Cuenca-Estrella, M. Detection of imported histoplasmosis in serum of HIV-infected patients using a real-time PCR-based assay. Eur. J. Clin. Microbiol. Infect. Dis. 2006, 25, 665-668. [CrossRef] [PubMed]

60. Maubon, D.; Simon, S.; Aznar, C. Histoplasmosis diagnosis using a polymerase chain reaction method. Application on human samples in French Guiana, South America. Diagn. Microbiol. Infect. Dis. 2007, 58, 441-444. [CrossRef] [PubMed]

61. Toranzo, A.I.; Tiraboschi, I.N.; Fernandez, N.; Ibarra-Camou, B.; Rivas, M.C.; Lee, W.; Davel, G.; Canteros, C.E. Molecular diagnosis of human histoplasmosis in whole blood samples. Rev. Argent. Microbiol. 2009, 41, 20-26. [PubMed]

62. Gago, S.; Esteban, C.; Valero, C.; Zaragoza, O.; Puig de la Bellacasa, J.; Buitrago, M.J. A multiplex real-time PCR assay for identification of Pneumocystis jirovecii, Histoplasma capsulatum, and Cryptococcus neoformans/Cryptococcus gattii in samples from AIDS patients with opportunistic pneumonia. J. Clin. Microbiol. 2014, 52, 1168-1176. [CrossRef] [PubMed]

63. Kolia-Diafouka, P.; Carrere-Kremer, S.; Lounnas, M.; Bourdin, A.; Kremer, L.; Van de Perre, P.; Godreuil, S.; Tuaillon, E. Detection of Mycobacterium tuberculosis in paucibacillary sputum: Performances of the Xpert MTB/RIF ultra compared to the Xpert MTB/RIF, and IS6110 PCR. Diagn. Microbiol. Infect. Dis. 2019, 94, 365-370. [CrossRef] [PubMed] 
64. Opota, O.; Mazza-Stalder, J.; Greub, G.; Jaton, K. The rapid molecular test Xpert MTB/RIF ultra: Towards improved tuberculosis diagnosis and rifampicin resistance detection. Clin. Microbiol. Infect. 2019. [CrossRef] [PubMed]

65. WHO. World Health Organization Model List of Essential In Vitro Diagnostics First Edition 2018. Available online: https://www.who.int/medical_devices/diagnostics/WHO_EDL_2018.pdf (accessed on 14 July 2019).

66. WHO. Second WHO Model List of Essential In Vitro Diagnostics Second edition 2019. Available online: https: //www.who.int/medical_devices/publications/Standalone_document_v8.pdf?ua=1 (accessed on 14 July 2019).

67. WHO. Guidelines for Managing Advanced HIV Disease and Rapid Initiation of Antiretroviral Therapy 2017. Available online: https://www.who.int/hiv/pub/guidelines/advanced-HIV-disease/en/ (accessed on 14 July 2019).

68. Wheat, L.J.; Freifeld, A.G.; Kleiman, M.B.; Baddley, J.W.; McKinsey, D.S.; Loyd, J.E.; Kauffman, C.A.; Infectious Diseases Society of America. Clinical practice guidelines for the management of patients with histoplasmosis: 2007 update by the Infectious Diseases Society of America. Clin. Infect. Dis. 2007, 45, 807-825. [PubMed]

69. Agudelo, C.A.; Restrepo, C.A.; Molina, D.A.; Tobon, A.M.; Kauffman, C.A.; Murillo, C.; Restrepo, A. Tuberculosis and histoplasmosis co-infection in AIDS patients. Am. J. Trop. Med. Hyg. 2012, 87, 1094-1098.

70. Melzani, A.; De Reynal De Saint Michel, R.; Ntab, B.; Djossou, F.; Epelboin, L.; Nacher, M.; Blanchet, D.; Demar, M.; Couppie, P.; Adenis, A. Incidence and trends in immune reconstitution inflammatory syndrome associated with Histoplasma capsulatum among people living with HIV: A 20-year case series and literature review. Clin. Infect. Dis. 2019. [CrossRef] [PubMed]

(C) 2019 by the authors. Licensee MDPI, Basel, Switzerland. This article is an open access article distributed under the terms and conditions of the Creative Commons Attribution (CC BY) license (http://creativecommons.org/licenses/by/4.0/). 